\title{
Abnormal Hippocampal Axon Bundling in EphB Receptor Mutant Mice
}

\author{
Zhi-Yong Chen, ${ }^{1}$ Chunhua Sun, ${ }^{1}$ Kenneth Reuhl, ${ }^{2}$ Andrew Bergemann, ${ }^{4}$ Mark Henkemeyer, ${ }^{5}$ and Renping Zhou ${ }^{1,3}$ \\ Departments of ${ }^{1}$ Chemical Biology and ${ }^{2}$ Pharmacology, College of Pharmacy, Rutgers University, and ${ }^{3}$ Department of Neuroscience and Cell Biology, \\ Robert Wood Johnson Medical School, Piscataway, New Jersey 08854, ${ }^{4}$ Department of Pathology, Mount Sinai School of Medicine, New York, New York \\ 10029, and ${ }^{5}$ Center for Developmental Biology, University of Texas Southwestern Medical Center, Dallas, Texas 75235
}

\begin{abstract}
Axons travel frequently in bundles to reach their target. After arriving at the target, axon terminals defasciculate, migrate to topographically defined positions, and form synapses with appropriate target neurons. Here we present evidence that the B-type receptors of the erythropoietin-producing hepatocellular (Eph) family and a ligand, ephrin-B3, influence hippocampal axon defasciculation. The EphB receptors are expressed in the hippocampus, and the ligand, ephrin-B3, is transcribed in the lateral septum, the major subcortical target of hippocampal neurons. Ephrin-B3 promotes adhesion of hippocampal neurons to the ligand-expressing substrates in vitro, and the loss of the receptor EphB2 abrogates the effects of ephrin-B3. In mice deficient in EphB2 and EphB3, many hippocampal axons remain in bundles. This phenotype was also observed in mice that were specifically deleted for the cytoplasmic domain of EphB2. These observations indicate that the EphB receptors and their ligand regulate hippocampal axon defasciculation at the septal target, possibly through a receptor-mediated forward signaling mechanism.
\end{abstract}

Key words: Eph receptors; axon fasciculation; hippocampus; cell adhesion; ephrin-B3; EphB2

\section{Introduction}

Selective fasciculation and defasciculation of axons play critical roles in the development of axon pathways in both invertebrate and vertebrate animals (Rutishauser, 1985; Tessier-Lavigne and Goodman, 1996). During development, pioneer axons first navigate through complex microenvironments to reach their targets. Axons developing later in the same pathway fasciculate with and migrate along the pioneer axons (Rutishauser, 1985); however, defasciculation must occur when axons reach either an intermediate choice point for a different pathway or the final target to allow axons to leave the fascicle. Failure to fasciculate or defasciculate properly results in mistargeting (Lin et al., 1994; Fambrough and Goodman, 1996; Yu et al., 2000).

Fasciculation and defasciculation are regulated by interactions among axons and between axons and the environment. Signals increasing axon-axon adhesion or decreasing axonenvironment interaction are likely to promote fasciculation. Conversely, signals that decrease axon-axon adhesion and increase axon-environment interaction may lead to defasciculation. Although a number of cell adhesion molecules (CAMs) including neural CAM (NCAM), L1, and neuron-glia CAM ( $\mathrm{NgCAM})$, have been shown to increase axon-axon interaction and mediate axon fasciculation (Thanos et al., 1984; TessierLavigne and Goodman, 1996), the mechanisms that regulate

Received 0ct. 17, 2003; revised Dec. 2, 2003; accepted Jan. 11, 2004.

This work was supported by the National Institutes of Health, the National Science Foundation, and the New Jersey Governor's Council on Autism (R.Z.), and by the March of Dimes Birth Defects Foundation and the Muscular Dystrophy Association (M.H.).

Correspondence should be addressed to Renping Zhou, Department of Chemical Biology, College of Pharmacy, Rutgers University, Piscataway, NJ 08854. E-mail: rzhou@rci.rutgers.edu.

DOI:10.1523/JNEUROSCI.4711-03.2004

Copyright $\odot 2004$ Society for Neuroscience $\quad 0270-6474 / 04 / 242366-09 \$ 15.00 / 0$ axon defasciculation have not been well characterized. Downregulation of adhesive activity of NCAM by the addition of the negatively charged carbohydrate polysiatic acid has been implicated in promoting axon defasciculation (Rutishauser, 1985). In Drosophila, a secreted Ig superfamily protein encoded by the beaten path gene also regulates defasciculation (Fambrough and Goodman, 1996).

We present evidence here for a novel mechanism that regulates axon defasciculation using the erythropoietin-producing hepatocellular (Eph) family tyrosine kinase receptors, EphB2 and EphB3. The Eph family consists of the EphA- and EphB-type receptors, defined by sequence homology and specificity of interaction with the ligands of this family, the ephrins. There are eight known EphA receptors that interact preferentially with the A-type ephrins, and six different EphB receptors that bind to the B-ephrins (for review, see Pasquale, 1997; Flanagan and Vanderhaeghen, 1998; Zhou, 1998). Both types of Eph receptors have been implicated in axon guidance and targeting and in tissue patterning (Drescher, 2000; Holder et al., 2000; Wilkinson, 2000; Kullander and Klein, 2002). During the development of the hippocamposeptal pathway, hippocampal axons travel in fascicles along the fornix-fimbria to reach the major subcortical target, the lateral septum. After arriving at the target, hippocampal axons defasciculate and spread topographically such that axons of the medial hippocampal neurons terminate in the dorsomedial region, whereas axons of the lateral neurons terminate in the ventrolateral area of the septal target (Swanson et al., 1987; Yue et al., 2002). We show here that mice deficient in EphB2 and EphB3 have abnormal hippocampal axon bundles at the septal target. Both receptors are expressed in hippocampal neurons, and a ligand, ephrin-B3, is transcribed in the septal target. Furthermore, ephrin-B3 promotes hippocampal cell adhesion and spreading on 
the ligand-expressing substrates in vitro. These observations suggest that the EphB receptors contribute to the regulation of defasciculation of hippocampal axons in the target field, possibly through promoting axon adhesion to the ligand-expressing projection target.

\section{Materials and Methods}

Tracing the hippocamposeptal pathway. For tracing adult hippocampal axons, mice were anesthetized with Nembutal ( $50 \mathrm{mg} / \mathrm{kg}$ body weight, i.p.). Fluoro-ruby [tetramethylrhodamine dextran, 10,000 molecular weight; Molecular Probes (Eugene, OR), D-1817) suspension (10\% in saline) was stereotaxically injected into medial or lateral hippocampus with iontophoresis $(8 \mu \mathrm{A}$, positive alternating current for $30 \mathrm{~min}$ ) under surgical microscope. One week after injection, labeled animals were perfused with $4 \%$ phosphate-buffered (0.1 M, pH 7.4) paraformaldehyde solution. The brains were dissected, postfixed for $24 \mathrm{hr}$ in $4 \%$ paraformaldehyde solution, and then incubated in 30\% sucrose in PBS until the brains settled to the bottom of the container. Coronal sections $(100 \mu \mathrm{m})$ were cut with a vibratome, collected in phosphate buffer (0.1 M, pH 7.4), and mounted on slides treated with poly-L-lysine. The sections were then examined with a Zeiss Axioskop connected to a digital camera, and images were processed using ImagePro Plus. Confocal images were taken with a Zeiss confocal imaging system (Model LSM510).

To trace hippocampal axons in embryos or early postnatal mice, dissected brains were first fixed in $4 \%$ phosphate-buffered $(0.1 \mathrm{M}, \mathrm{pH} 7.4)$ paraformaldehyde solution for 1 week and then incubated in 30\% sucrose in PBS until the brains settled to the bottom of the container. Crystal DiI (Molecular Probes, D-3911) was inserted into the lateral hippocampal regions. The labeled brains were incubated at $37^{\circ} \mathrm{C}$ in $30 \%$ sucrose- $4 \%$ paraformaldehyde solution for 2 months and then sectioned and analyzed as described above.

In situ hybridization. Embryonic day (E) 18 $\mathrm{CD}-1$ mouse embryos and early postnatal $(\mathrm{P})$ mice (P5 and P7) (Charles River Laboratories, Wilmington, MA) were used in in situ hybridization experiments. At least three animals were investigated for each developmental stage. The mothers were anesthetized with nembutal $(50 \mathrm{mg} / \mathrm{kg}$ body weight, i.p.), the embryos were dissected and decapitated, and the heads were frozen on dry-ice powder. For postnatal mice, brains were dissected and frozen on dry ice as well. Sagittal sections of $12 \mu \mathrm{m}$ thickness were cut with a cryostat at $-23^{\circ} \mathrm{C}$ and mounted on VWR Scientific superfrost slides. The slides were then stored at $-80^{\circ} \mathrm{C}$ before use.

In situ hybridization was performed with ${ }^{35} \mathrm{~S}$ - or digoxigenin-labeled in vitro transcribed riboprobes as described previously (Zhang et al., 1997). Briefly, slide-mounted sections were fixed in $4 \%$ paraformaldehyde in $0.1 \mathrm{M}$ ] phosphate buffer, $\mathrm{pH} 7.2$ (all treatments were performed at room temperature unless indicated otherwise). To hybridize with riboprobes, the sections were treated with proteinase $\mathrm{K}(40 \mathrm{ng} / \mathrm{ml})$, refixed with $4 \%$ paraformaldehyde, immersed in triethanolamine $(50 \mathrm{~mm})$ in acetic anhydride solutions (100 $\mathrm{mm}$ ) for $10 \mathrm{~min}$, and dehydrated. The sections were hybridized with the respective ${ }^{35} \mathrm{~S}-\left(2.5 \times 10^{6} \mathrm{cpm} / \mathrm{ml}\right)$ or digoxigenin-labeled riboprobes under stringent conditions ( $50 \%$ formamide, $10 \%$ dextran sulfate, $1 \times$ Denhardt's solution, $0.2 \mathrm{mg} / \mathrm{ml}$ herring sperm DNA, and $10 \mathrm{~mm}$ dithiothreitol) for $18-24 \mathrm{hr}$ at $55^{\circ} \mathrm{C}$. After hybrid- ization, the sections were washed in $5 \times \mathrm{SSC}$ at $65^{\circ} \mathrm{C}$ for $20 \mathrm{~min}$, followed by $50 \%$ formamide in $2 \times$ SSC for $30 \mathrm{~min}$ at the same temperature. The sections were washed twice in RNase buffer (10 mM Tris- $\mathrm{HCl}, \mathrm{pH} 7.5,0.5 \mathrm{M} \mathrm{NaCl}$, and $5 \mathrm{~mm}$ EDTA) for $20 \mathrm{~min}$ each and incubated for $30 \mathrm{~min}$ at $37^{\circ} \mathrm{C}$ in the same buffer containing $20 \mu \mathrm{g} / \mathrm{ml}$ RNase A. Sections were then rinsed in the RNase buffer for $20 \mathrm{~min}$ at $37^{\circ} \mathrm{C}$. Finally, the sections were washed in $50 \%$ formamide, $2 \times \mathrm{SSC}$ at $65^{\circ} \mathrm{C}$ for $30 \mathrm{~min}$ and in $2 \times$ SSC and $0.1 \times$ SSC at room temperature for $15 \mathrm{~min}$, respectively. After washes, ${ }^{35} \mathrm{~S}$-labeled sections were dehydrated and exposed to $\mathrm{x}$-ray film for 3-6 d. After film development, the sections were coated with Kodak NTB-2 photographic emulsion, diluted 1:1 with distilled water. The sections were exposed for $2-3$ weeks at $4^{\circ} \mathrm{C}$, developed, and counterstained with thionin $(0.25 \%$ in $10 \%$ acetic acid adjusted to $\mathrm{pH} 4$ with $\mathrm{NaOH}$ ). Digoxigenin-labeled sections were incubated with alkaline phosphatase (AP)-conjugated anti-digoxigenin antibody (Roche, cata$\log \# 1093274)$ at $4^{\circ} \mathrm{C}$ overnight, followed by color development according to the manufacturer's instructions. Sense probes were used as controls and showed no specific hybridization signals.

Expression of ephrin-B3 ligand in NIH-3T3 cells. Mouse ephrin-B3 was cloned into a retroviral vector pLIG (Lillien, 1995), which contains a 
$\beta$-galactosidase gene fused to an aminoglycoside phosphotransferase for G418 resistance. The construct was then transfected into NIH-3T3 as described (Gao et al., 1996). G418-resistant colonies were then screened for ephrin-B3 expression by EphB3-AP fusion protein binding. EphB3-AP binds strongly to ephrin-B3-expressing NIH-3T3 cells but did not have significant binding to parental or empty vector-transfected NIH-3T3 cells.

Primary neuron culture. The hippocampi from E18 rat or E16 mouse embryos were dissected in PBS, dissociated into a single-cell suspension by mechanically passing through polished glass pipettes, and counted under a microscope. Neurons were plated in 12 -well dishes $\left(10^{5}\right.$ per well $)$ preseeded with a confluent monolayer of ephrinexpressing or control NIH-3T3 cells transfected with the empty vector in DMEM supplemented with fetal bovine serum (10\%), penicillin (1 $\mathrm{U} / \mathrm{ml})$, and streptomycin $(1 \mathrm{U} / \mathrm{ml})$. The cocultures were maintained for $48 \mathrm{hr}$, fixed with $4 \%$ paraformaldehyde in PBS, and then immunocytochemically stained with anti-neuron-specific enolase (for rat neurons) (Gao et al., 1996) or antineurofilament $\mathrm{H}$ (for mouse neurons) antibodies using Vectastain $\mathrm{ABC}$ kit (Vector Laboratories, Burlingame, CA). The stained neurons were examined under a Nikon Eclipse TE200 microscope, and the images were captured and quantified with the ImagePro Plus program.

Quantification of cell aggregation and axon bundle thickness. Hippocampal neuron aggregates of similar size on control or ephrin-B3expressing cells were selected for quantification. For each aggregate, the diameters of all axonal bundles were measured. The measurement was done on axons near their exit point. At least 100 bundles were surveyed for each sample assayed. To quantify effects on cell aggregation, the numbers of unaggregated individual neurons in 20 random fields were counted in cultures with ephrin-B3-expressing or control cell line. The ratio between the numbers of unaggregated neurons in ephrin-B3 coculture and the control coculture was calculated as dissociation index. The dissociation index on control cells was set as 1 .

Quantification of axon terminal density. The bitmap of the lateral septal terminal area was calculated with ImagePro Plus software. The bitmap is a two-dimensional array used to represent an image in a computer. Each cell in the array contains a value that describes a sample of the image in terms of its color and intensity.

\section{Results}

Abnormal bundling of hippocampal axons in the lateral septum in

\section{EphB2/B3-null mice}

To examine roles of the EphB-type receptors and ligands in hippocampal axon projections, the axon pathway and terminal regions were analyzed using the axon-tracking dye Fluoro-ruby in adult mice homozygous for protein-null mutations in $\operatorname{EphB} 2\left(\mathrm{EphB}^{-/-}\right)$and EphB3 (EphB3 $\left.{ }^{-1-}\right)$. Fluoro-ruby was injected stereotaxically in either the medial (Fig. $1 A$ ) or lateral (Fig. $1 B$ ) region of the hippocampus. These analyses revealed no gross differences in the $\mathrm{mm} ; F, 0.02 \mathrm{~mm}$.
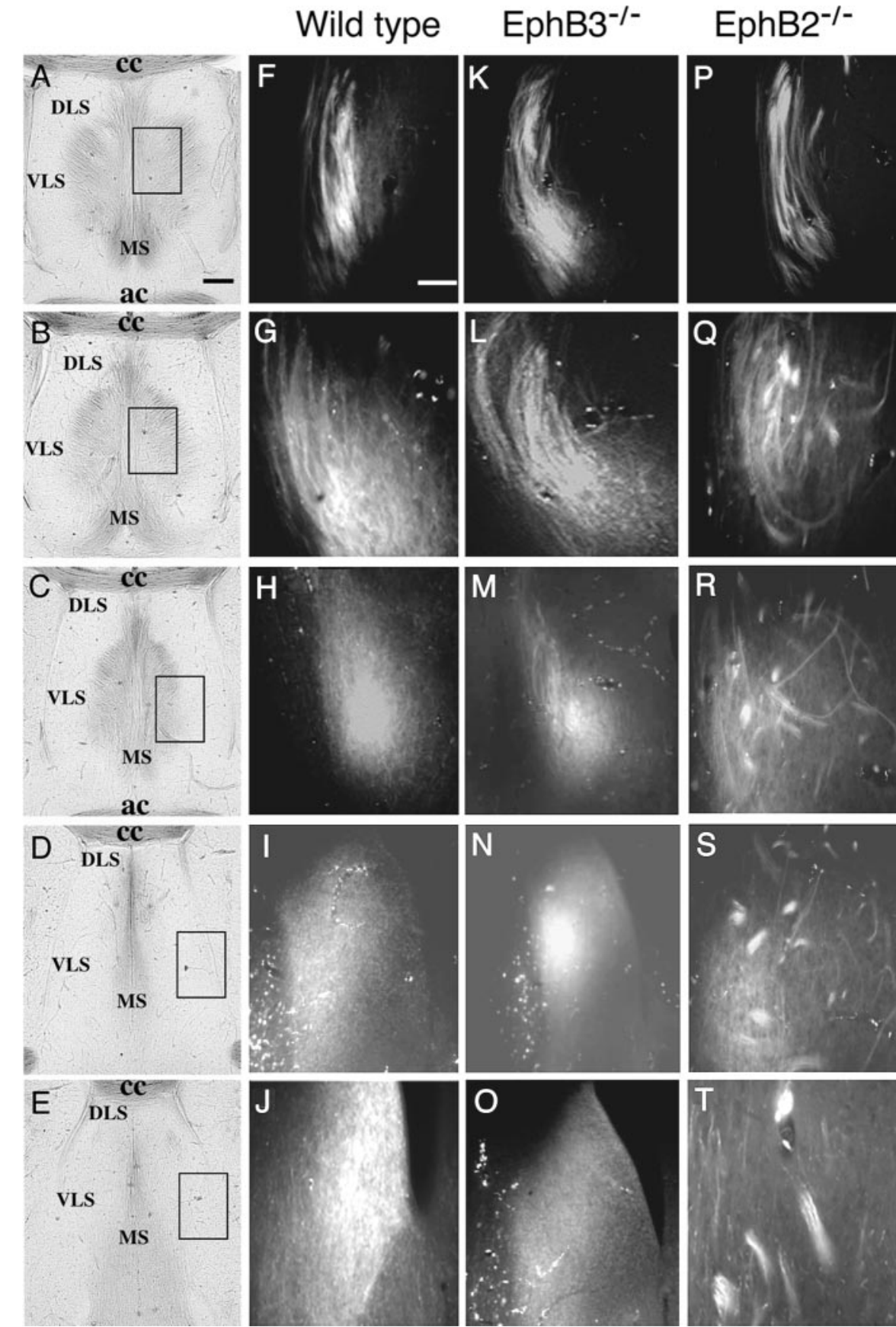

Figure 2. Increased axon bundling in the terminal area of lateral hippocampal axons in the lateral septum in EphB receptornull mice. Fluoro-ruby was injected into the lateral hippocampus to anterogradely label the lateral hippocampal axons. $A-E$, Bright-field photomicrographs of five different posterior to anterior coronal sections of a wild-type traced brain showing the major cytoarchitectural features of the septal region. These sections are $\sim 100 \mu \mathrm{m}$ apart. Boxes in $A-E$ indicate positions of dark-field panels on the right. $F-T$, Fluorescence photomicrographs of lateral hippocampal axon terminals at different posterior to anterior positions of wild-type $(F-J)$, EphB3 ${ }^{-/-}$single mutant $(K-0)$, and EphB2 ${ }^{-1-}$ single mutant $(P-T)$ mice. ac, Anterior commissure; $c c$, corpus callosum; DLS, dorsal lateral septum; MS, medial septum; VLS, ventral lateral septum. Scale bars: $A, 0.2$
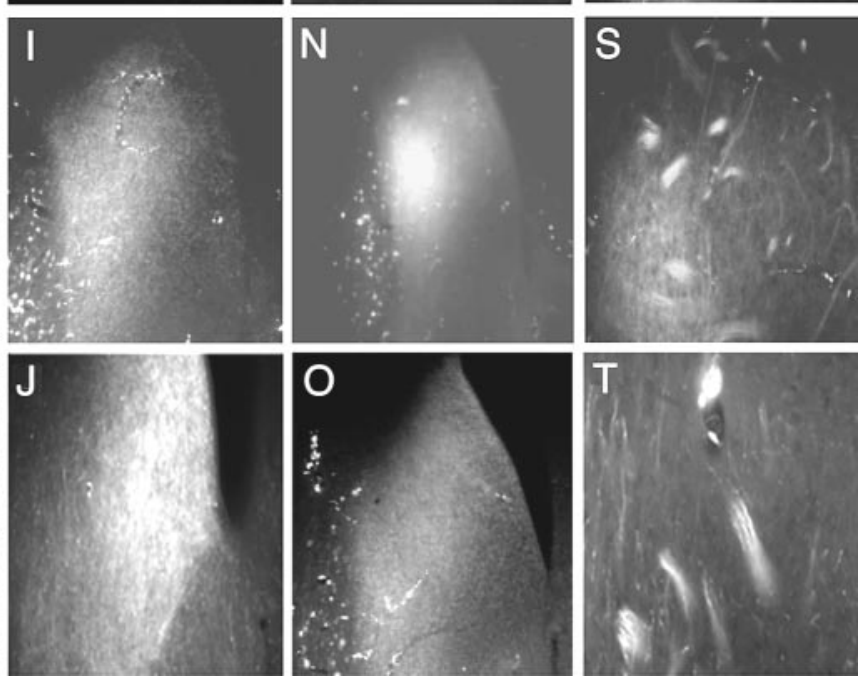

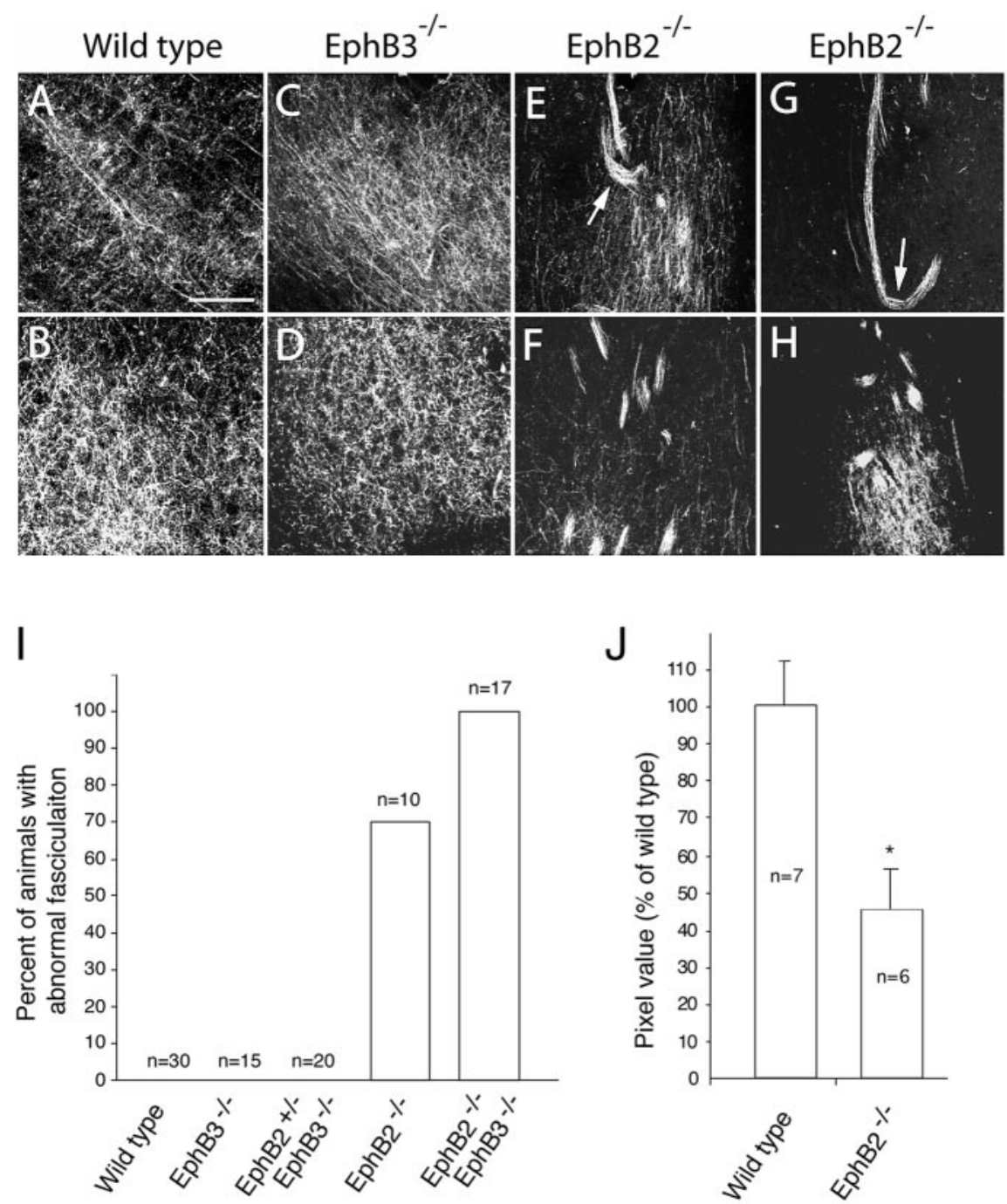

Figure 3. Density of lateral hippocampal axon terminals in the lateral septum is reduced in EphB2 ${ }^{-1-}$ knock-out mice. $A-H$,

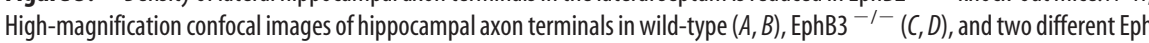
$B 2^{-I-}$ single mutant $(E-H)$ mice. Positions of top panels correspond to Figure $2 C$, and bottom panels correspond to Figure $2 E$. Arrows in $E$ and $G$ indicate axon bundles turning abnormally. I, Percentage of EphB knock-out animals with defasciculation defects. $J$, The density of the unbundled axon terminals in the EphB2 ${ }^{-1-}$ septum is significantly less than that of the wild-type septum. The pixel values of the unbundled axon terminals were measured using ImagePro image analysis software. Axon bundles were excluded from analysis. Asterisk indicates significant differences ( $p<0.05 ; t$ test). Scale bar, $0.05 \mathrm{~mm}$.

pocampal axons exit the fornix and defasciculate to form fine terminal arbors (Figs. $2 H-J, 3 A, B$ ). In contrast, only part of the hippocampal axons in EphB2-null mice form fine terminal arbors, and many fibers stay bundled (Fig. 2Q-T). In addition, some of the fiber bundles appear to have abnormal turns (Fig. $3 E, G)$. This failure to defasciculate was specific for the lateral hippocampal axons, because the medial axons appeared to defasciculate normally in the EphB2-null brains (Fig. $1 C-H$ ).

Approximately $70 \%$ of the EphB2-null homozygous adult mice analyzed by this method showed defects in hippocampal axon defasciculation $(n=10)$ (Fig. 3I). In contrast, abnormal axon bundling was not observed in the EphB3-null mice $(n=35)$ (Figs. $2 \mathrm{~K}-\mathrm{O}, 3 \mathrm{C}, \mathrm{D}, I)$. Although EphB3 does not seem to play a key role in regulating hippocampal axon defasciculation, it may partially compensate for the loss of EphB2, because 100\% of the EphB2 ${ }^{-/-}$EphB3 ${ }^{-/-}$compound homozygous mice showed this defect $(n=17)$ (Fig. 3I). Importantly, no abnormal fascicles were observed in the 30 adult wild-type brains examined in this anal- ysis (Fig. 3I). Thus, EphB2 and EphB3 have partially redundant functions. Consistent with the inability to defasciculate, the density of unbundled hippocampal axon terminals in the lateral septum is also significantly reduced in the mutants (Fig. 3J).

\section{Defasciculation deficiencies in developing EphB2-null mice}

To examine whether the presence of abnormal hippocampal axon bundles in the adult mutant mice is caused by a failure to defasciculate initially when the axons first arrive at the target or by a defect in synapse formation after the axons have taken up their appropriate positions, hippocampal axon morphology was analyzed in E18 and P0 brains. The fixed brains were labeled by inserting DiI crystals into the lateral hippocampal regions, and after a further incubation of 2 months, the labeled brains were sectioned and analyzed as described in Materials and Methods. Large hippocampal axon bundles were observed in the lateral septum in both the E18 and P0 EphB2 ${ }^{-1-}$ mouse brains but not in wildtype controls (Fig. 4), suggesting that the abnormal axon bundles in EphB2 ${ }^{-1-}$ mice developed because of failures of hippocampal axons to defasciculate after they arrived at the target.

\section{Expression of EphB receptors in the hippocampus and ephrin-B ligands in the lateral septum}

The defasciculation defect in EphB2 ${ }^{-/-}$and EphB2 ${ }^{-1-}$ EphB3 $^{-1-}$ mutant mice suggests that these receptors regulate hippocampal axon pathfinding and targeting and predicts that these receptors are expressed in the hippocampal neurons. To test this prediction, the expression of these two receptors was examined using an in situ hybridization technique. Consistent with previous reports (Grunwald et al., 2001; Henderson et al., 2001), our analyses show that during late embryonic and early postnatal development, when hippocampal axons are actively targeting the septum (Linke et al., 1995), EphB2 and EphB3 are expressed in the hippocampus (Fig. 5 and data not shown). In contrast to the graded expression of EphA5 receptor (Gao et al., 1996; Zhang et al., 1997; Yue et al., 2002), EphB2 and EphB3 are expressed throughout the hippocampus, at similar levels in the medial and lateral regions (Fig. $5 C-F$ ). The presence of EphB2 and EphB3 transcripts in the hippocampus are consistent with roles in hippocampal axon defasciculation. In addition to EphB2 and EphB3 receptors, EphB1 is also expressed in the developing hippocampus; however, expression of this receptor is restricted to the medial hippocampus (Fig. 5B).

To examine which ephrin-B ligands potentially interact with EphB2 and EphB3 at the septal target, the expression patterns of all three B-class ephrins were examined. In E18 mouse embryonic brain, ephrin-B1 mRNA was detected in the ventricular zone but 
not in the lateral septum (Fig. 6B). Ephrin-B2 was not significantly expressed in the lateral septum, although low levels were detected in the medical septum (Fig. $6 C)$. In contrast, high levels of ephrin-B3 transcripts were detected in the entire septal region (Fig. 6D). Ephrin-B3 expression persisted in early postnatal mice (P5) (data not shown). These results suggest that ephrin-B3 may mediate the functions of EphB2 and EphB3 in axon defasciculation in the septal target.

Ephrin-B3 promotes hippocampal cell spreading and adhesion to the ligandexpressing substrates in vitro

One way the EphB receptors and ligands may influence hippocampal axon defasciculation is to promote adhesion of hippocampal axons onto the ligand-expressing substrates. To examine whether ephrin-B3 regulates hippocampal cell adhesion, the effects of ephrin-B3 were analyzed using an in vitro coculture assay. Ephrin-B3 was cloned into a retroviral expression vector (Lillien, 1995) under the transcriptional control of the viral long terminal repeat. The expression cassette was then transfected into mouse fibroblast NIH-3T3 cells, and independent neo-resistant clones were examined for ephrin-B3 expression using EphB3-alkaline phosphatase binding. Several lines that express high levels of ephrin-B3 were obtained. Hippocampal neurons from E18 rat embryos were then cocultured with cells expressing ephrin-B3, and the neurons were detected using anti-neuron-specific enolase immunocytochemistry. When the neurons were cocultured with cells transfected with empty expression vector, the neurons formed large aggregates and the axons formed thick bundles (Fig. 7A). In contrast, when cocultured with ephrin-B3-expressing cells, hippocampal neurons appeared more dispersed, and the axons did not form thick fascicles (Fig. $7 B, C$ ). Quantitative measurement indicated that more neurons stayed as individual cells and that axon bundles were significantly thinner in the presence of ephrin-B3 compared with controls (Fig. 7D,E). These effects were reproduced with several independent ephrin-B3expressing cell lines; the results from two of the lines (G6 and G10) are reported here (Fig. 7). These observations suggest that ephrin-B3 may promote hippocampal axon adhesion to the ligand-expressing projection target, thereby inducing defasciculation.

\section{Inactivation of EphB receptors prevents ephrin-B3-induced substrate adhesion in vitro}

To examine whether the effects of ephrin-B3 are mediated through the interaction with EphB2 and EphB3, hippocampal neurons with inactivated EphB2 and EphB3 were examined for their responses to ephrin-B3. E16 mouse embryonic hippocampal neurons from the wild type scattered, and their axons defasciculated in the presence of ephrin-B3 (Fig. 8A,B,G,H). Hippocampal neurons with inactivated EphB3 showed a similar response to that of wild-type neurons (Fig. $8 C, D, G, H$ ). In contrast, the response to ephrin-B3 was lost in neurons lacking EphB2 receptor (Fig. $8 E-H$ ). These neurons remained aggregated even in the presence of ephrin-B3. These in vitro observations are consistent with the in vivo data indicating that EphB2 is the major regulator for hippocampal axon defasciculation.
Wild Type
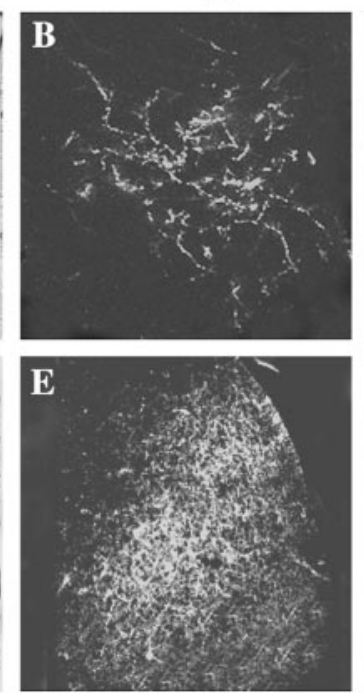

EphB2$^{-/-}$

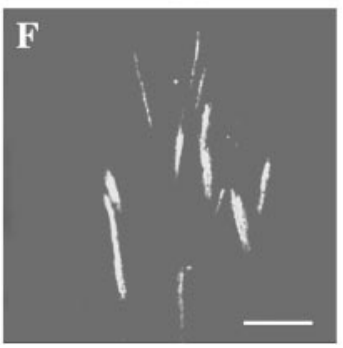

MS

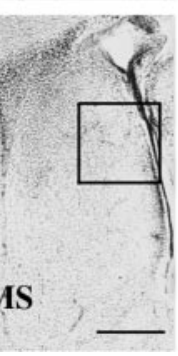

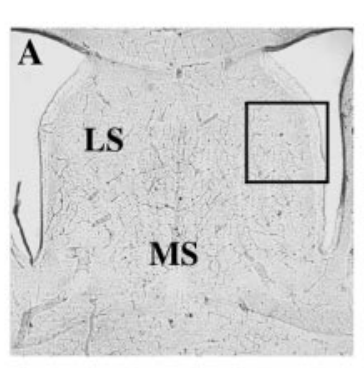
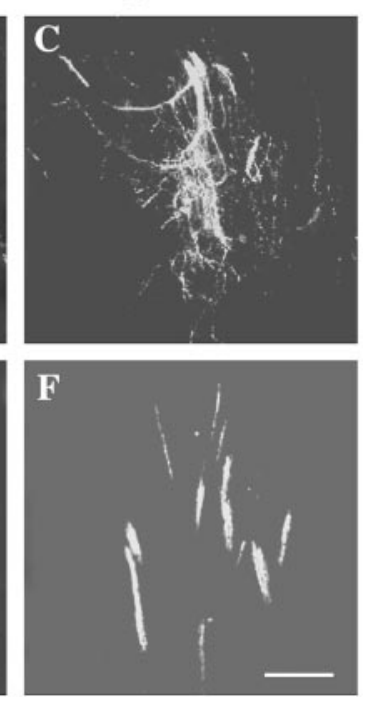

Higure 4. Hippocampal axon defasciculation defects in embryonic and newborn EphB-null mice. Dil was placed in the latera the septal region. $B, E$, Defasciculated hippocampal axons in the lateral septum of wild-type mouse brains. $C, F$, Abnormal hippocampal axon bundles in the lateral septum of the EphB2 ${ }^{-1-}$ mutant mice. Images in $B, C, E$, and $F$ are from the boxed area in $A$ and $D$. Scale bars: $B, 0.25 \mathrm{~mm} ; F, 0.05 \mathrm{~mm}$.

\section{The cytoplasmic domain of EphB2 is required for} hippocampal axon defasciculation

Because both the EphB receptors and their ligands, the B-ephrins, transduce signals (Cowan and Henkemeyer, 2002; Kullander and Klein, 2002), axon defasciculation could be regulated through either receptor (forward) or ligand (reverse) signaling. Analysis of EphB2 $2^{-I-}$ mice does not distinguish between these two pathways because both pathways have been affected in these mice. To determine whether defasciculation is regulated by EphB forward signaling, axon morphology was analyzed in homozygous mice that carry a specific deletion of the cytoplasmic domain of EphB2, including its tyrosine kinase domain (EphB2 ${ }^{\mathrm{ki} / \mathrm{ki}}$ ) (Henkemeyer et al., 1996). Tracing analysis with Fluoro-ruby injected in the hippocampus revealed that hippocampal axons also failed to defasciculate in $44 \%$ (four of nine) of the homozygous kinaseinactive EphB2 ${ }^{\mathrm{ki} / \mathrm{ki}}$ mice (Fig. 9). In addition, axon bundles are clearly visible in vibratome sections under bright-field illumination (Fig. 9B, C). These data show that regulation of hippocampal axon defasciculation is dependent on the cytoplasmic domain of EphB2 receptor and indicate that forward signaling mediated by the EphB2 cytoplasmic domain is important.

\section{Discussion}

Axons in many major pathways travel to their targets as fasciculated bundles. Examples include corpus callosum, anterior commissure, corticospinal tract, and the optical nerve, as well as the fornix-fimbria that interconnects the hippocampus with its subcortical targets. After arriving at their final destination, axons must defasciculate to form terminal arbors and synapse with target neurons. Defasciculation is also required for axons to exit the bundle at intermediate choice points. Here we present evidence that EphB receptors regulate hippocampal axon defasciculation at the septal target. Consistent with this notion, EphB2 and EphB3 receptors are expressed in the hippocampal pyramidal neurons, whereas ephrin-B3 is expressed at the septal target, the lateral septum. Inactivation of EphB2 and EphB3 receptors in 
Thionin

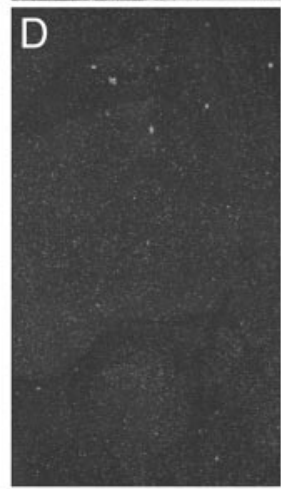

EphB2 control

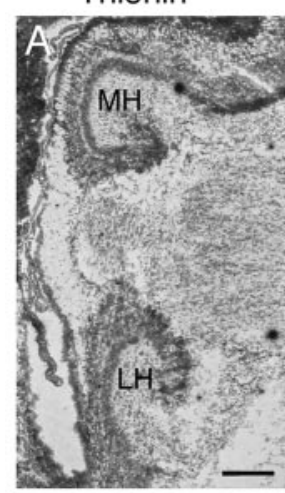

EphB1

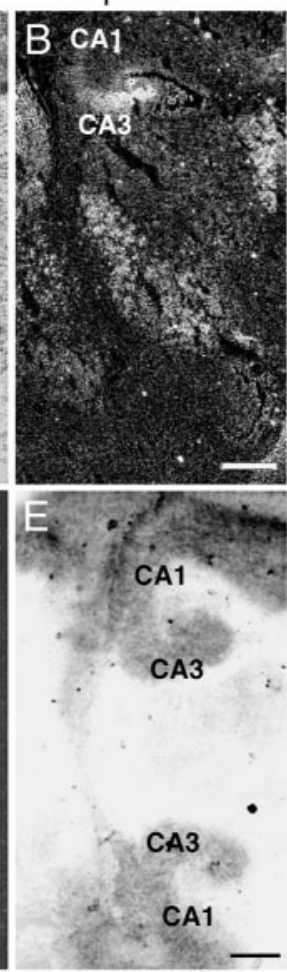

EphB3

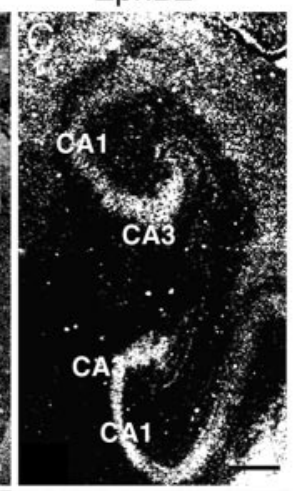

$\mathrm{F}$

\section{EphB2}

Figure 5. Expression of EphB receptors in the hippocampus. Sagittal hippocampal sections of E18 mouse embryos were hybridized with ${ }^{35} \mathrm{~S}$ - or digoxigenin-labeled RNA probes. A, Brightfield photomicrograph of a hybridized sagittal mouse hippocampal section stained with thionin for cytoarchitecture reference. $B, C$, Dark-field photomicrographs of mouse hippocampal sections hybridized with ${ }^{35}$ S-labeled antisense riboprobes of EphB1 (B) and EphB2 (C). D, Darkfield photomicrographs of a similar section as shown in Chybridized with a control EphB2 sense riboprobe. E, F, Bright-field photomicrographs of hippocampal sections hybridized with digoxigenin-labeled antisense $(E)$ or control sense $(F)$ riboprobes of EphB3. MH and LH, Medial and lateral hippocampus. Scale bars, $0.5 \mathrm{~mm}$.

mice leads to abnormal bundling of hippocampal axon terminals in the lateral septum. In addition, exposure to ephrin-B3 results in an increased adhesion of hippocampal cells to the ligandexpressing substrates, and the loss of EphB2 function leads to a loss of response of hippocampal neurons to ephrin-B3 in vitro. Although previous studies have implicated Eph receptors in promoting axon fasciculation (Winslow et al., 1995; Orioli et al., 1996), observations shown here suggest that the EphB receptors can also induce defasciculation of specific axons during development, possibly through regulating axon adhesion to the substrates in the target tissue.

\section{EphB receptor forward signaling is required for hippocampal axon defasciculation}

The B-type Eph family receptors and ligands exert multiple functions during development through receptor tyrosine kinasemediated forward signaling or ligand intracellular domainmediated reverse signaling (for review, see Cowan and Henkemeyer, 2002; Kullander and Klein, 2002) (also see Henkemeyer et al., 1996; Kullander et al., 2001b; Yokoyama et al., 2001; Hindges et al., 2002; Mann et al., 2002; Palmer et al., 2002). Through forward signaling, ephrin-B1 has been shown to restrict neural crest cell migration and motor axon outgrowth to rostral somite halves by repulsion (Krull et al., 1997; Wang and Ander-

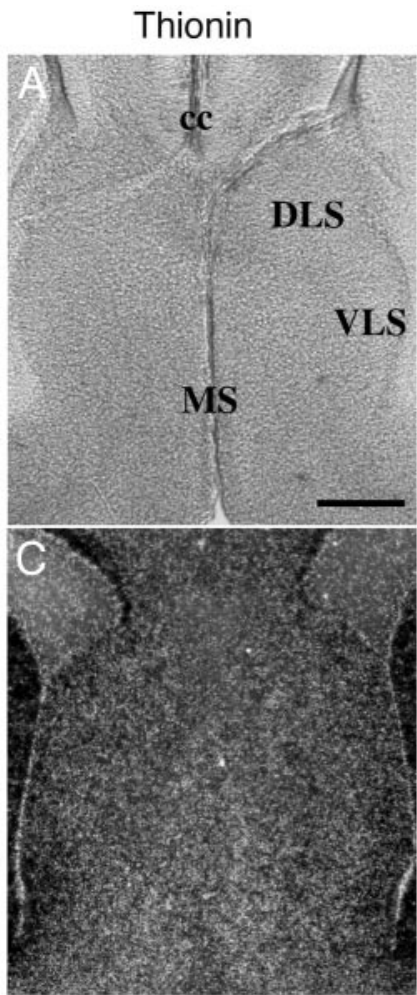

Ephrin-B2
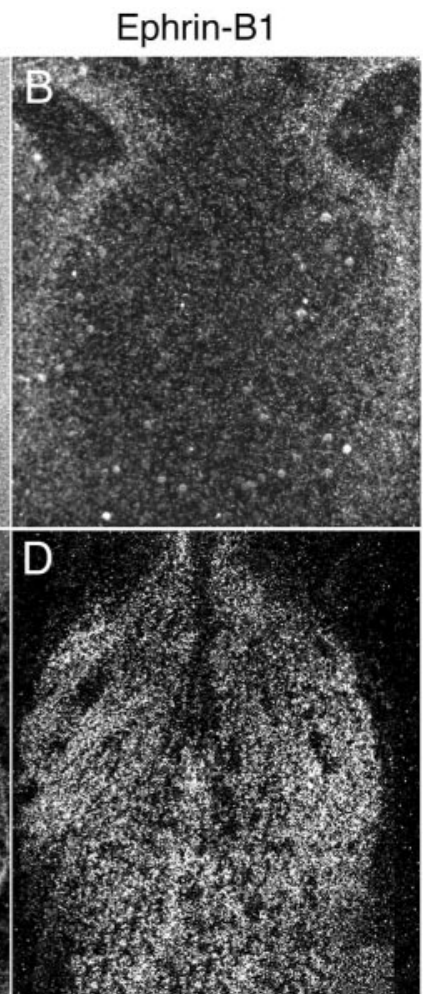

Ephrin-B3
Figure 6. Expression of the B-ephrins in the septum. Coronal sections of E18 mouse embryos were hybridized with ${ }^{35} S$-labeled riboprobes of the B-ephrins. $A$, Bright-field photomicrograph of a thionin-stained section of the mouse septum for cytoarchitecture reference. $B-D$, Dark-field photomicrographs of mouse brain sections containing the septum hybridized with riboprobes of ephrin-B1 (B), ephrin-B2 (C), and ephrin-B3 (D). Sense control probes showed no specific hybridization signals. cc, Corpus callosum; DLS, dorsal lateral septum; VLS, ventral lateral septum; MS, medial septum. Scale bar, $0.2 \mathrm{~mm}$.

son, 1997). Forward signaling by EphB2 regulates midline entry and crossing by the contralateral inner ear efferents (Cowan et al., 2000). EphB receptor-mediated forward signaling is also responsible for the ipsilateral routing of retinal ganglion axons at the optic chiasm and in regulating dorsal-ventral topographic mapping of retinal axons in the optic tectum (Nakagawa et al., 2000; Hindges et al., 2002).

Reverse signaling through the B-ephrin ligands has been shown to be important in regulating commissure axon pathway development. Inactivation of EphB2 leads to defects in pathfinding of anterior commissure axons (Henkemeyer et al., 1996). There is evidence that the effects of EphB2 on the development of anterior commissure are exerted through reverse signaling of the $\mathrm{B}$-ephrin ligands. It was shown that B-subclass ephrins are expressed on the commissure axons and mutant mice that carry a deletion of EphB2 tyrosine kinase but retain the extracellular ligand-binding domain of the receptor show normal anterior commissure (Henkemeyer et al., 1996). Similarly, EphA4 also regulates development of anterior commissure via a reverse signaling mechanism (Kullander et al., 2001a). Reverse signaling through B-ephrins has also been shown to be important for cell sorting in the hindbrain as well (Wang et al., 1998; Adams et al., 1999; Mellitzer et al., 1999; Xu et al., 1999). In addition, there is evidence that reverse signaling also occurs through ephrin-A ligands (Davy et al., 1999; Davy and Robbins, 2000; Knoll et al., 2001; Knoll and Drescher, 2002).

In reverse signaling, Eph receptors serve as ligands to activate 

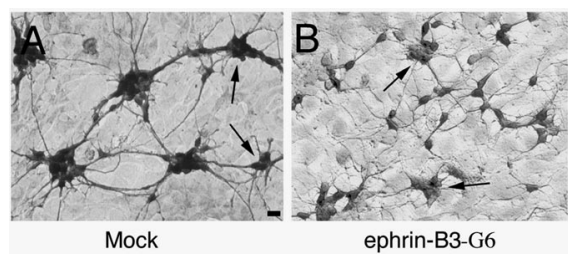

D

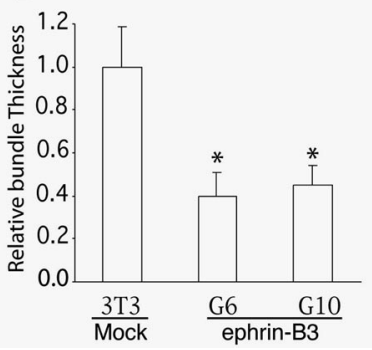

E

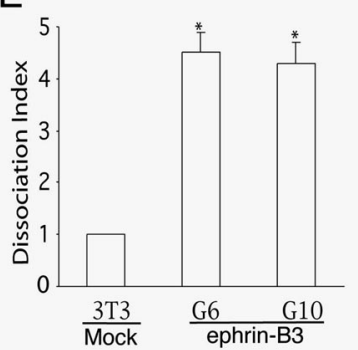

Figure 7. Effect of ephrin-B ligands on the aggregation and axon bundling of rat hippocampal neurons. A, Hippocampal neurons of E18 embryos ( $10^{5}$ per well of 12-well dish) were cocultured with control NIH-3T3 cells. B, C, E18 hippocampal neurons were cocultured with ephrin-B3-G6 ( $B$ ) or ephrin-B3-G10 ( $C$, two lines of ephrin-B3-expressing cells, respectively. The cocultures were maintained for $2 \mathrm{~d}$ and then stained with anti-neuron-specific enolase antibody. Arrows indicate aggregates with similar sizes from different cultures that were chosen for quantification. Scale bar, $20 \mu \mathrm{m}$. D, Relative bundle thickness. The diameter of all axonal bundles was measured from aggregates that had similar size in both control and ephrin-B3expressing cell lines. $E$, Neuron dissociation index. Dissociation index is the ratio of the number of individual unaggregated neurons in cocultures of ephrin-B3-expressing and control cells. Because the total number of neurons seeded on each well is the same $\left(10^{5}\right.$ per well of 12 -well Corning tissue culture dishes), the number of unaggregated individual cells is a measure of how aggregated the neurons are in the presence of ephrin- $\mathrm{B} 3$ compared with the controls. The dissociation index on control cells was regarded as 1 . Asterisk indicates statistical significance $(p<0.05 ; t$ test $)$

functions of ephrins, and thus the cytoplasmic region, including the kinase domain of the receptors, is dispensable. In contrast, forward signaling is autonomous for receptor-expressing cells and depends on the presence of full-length receptors. Regulation of hippocampal axon defasciculation is dependent on the EphB2 cytoplasmic domain and thus is likely mediated by receptor forward signaling through its tyrosine kinase activity. Because only $44 \%$ of the EphB2 ${ }^{\mathrm{ki} / \mathrm{ki}}$ mutants show defasciculation defects, however, a contribution by reverse signaling cannot be excluded completely. Nevertheless, a role for receptor forward signaling is consistent with the observation that EphB2 and EphB3 are highly expressed in the hippocampal neurons and that a high level of ephrin-B3 is transcribed in the septal target. These observations suggest that the target-expressed ephrin-B3 regulates defasciculation by stimulating EphB2 and EphB3 receptors. In addition, in vitro, ephrin-B3 expressed on the surface of NIH-3T3 cells promoted hippocampal cell adhesion, indicating that the ligand may regulate defasciculation by increasing axon-substrate interaction through binding to the EphB receptors expressed in the hippocampal neurons. Consistent with this, inactivation of EphB2 abrogates the ability of hippocampal axons to respond to ephrin$\mathrm{B} 3$. Together, these results indicate that EphB receptors expressed in the hippocampal neurons are responsible for transduction of defasciculation signals in hippocampal neurons.

It is possible that the failure of hippocampal axons to defasciculate in the EphB2-EphB3 mutants is caused by the failure of synapse formation with the target neurons, because EphB2 has been shown to be expressed in the synapses (Torres et al., 1998); however, there is no evidence that this is the case. First, the abnormal axon bundles are present at early stages of hippocampo-

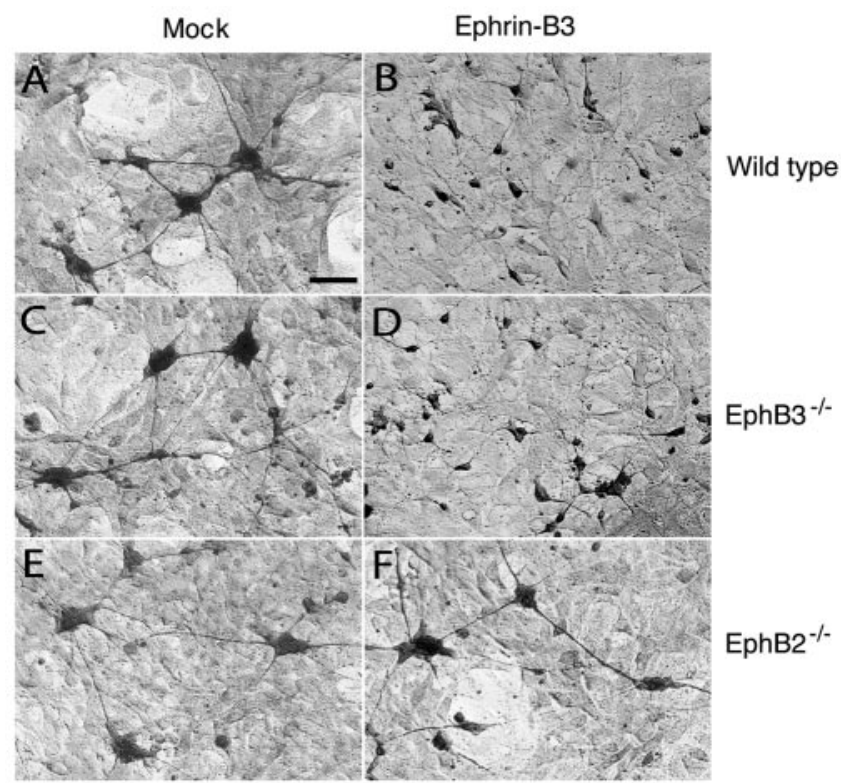

G

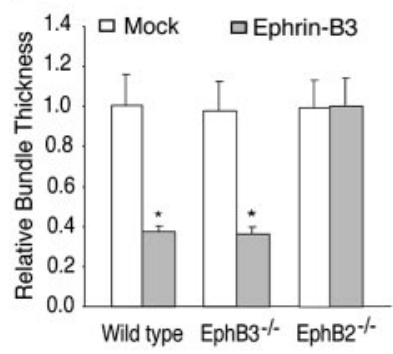

$\mathrm{H}$

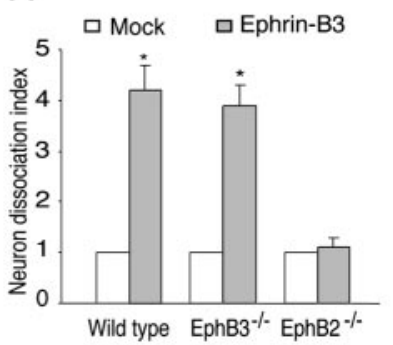

Figure 8. Effects of inactivation of EphB2 and EphB3 on the response of hippocampal neurons to ephrin-B3. $A, C, E, E 16$ hippocampal neurons from the wild-type $(A)$, EphB3 ${ }^{-1-}(C)$, and EphB2 ${ }^{-1-}(E)$ embryos were cocultured with a mock-transfected NIH-3T3 cell line. $B, D, F$, E16 hippocampal neurons from the wild-type $(B), \mathrm{EphB3}^{-1-}(D)$, and EphB2 ${ }^{-1-}(F)$ mouse embryos were cocultured with an ephrin-B3-expressing cell line (G6). The cultures were maintained for $2 \mathrm{~d}$ and then stained with anti-neurofilament $\mathrm{H}$ antibody. Scale bar, $0.1 \mathrm{~mm}$. $G$, Relative axon bundle diameter. $H$, Dissociation index. The diameter of axon bundles and the number of unaggregated neurons were quantified as described in Figure 7 and in Materials and Methods. Asterisk indicates statistical difference from the control ( $p<0.05 ; t$ test).

septal pathway development (E18), before extensive synaptogenesis occurs. Second, normal synaptic morphology was observed in the hippocampus of EphB2-null mice (Grunwald et al., 2001), suggesting that loss of EphB2 does not lead to defects in synapse formation. In addition, hippocampal axons defasciculate when cocultured with NIH-3T3 cells in the presence of ephrin-B3 expression, a condition under which normal synapse formation cannot occur, indicating that synapse formation is not necessary for axon defasciculation. Thus, it is likely that the EphB receptors directly regulate axon adhesion, through a forward signaling mechanism.

\section{Differences in regulation of defasciculation by the medial and} lateral hippocampal axons

Although the lateral hippocampal axons failed to defasciculate properly in EphB2 ${ }^{-1-}$ EphB3 ${ }^{-l-}$ mutant mice, the medial hippocampal axons defasciculated normally. It is not known at present what underlies the difference between the medial and the lateral hippocampal axons; however, it is possible that this is caused by compensation of the loss of EphB2 and EphB3 functions by EphB1. EphB1 is expressed in the medial but not the lateral 


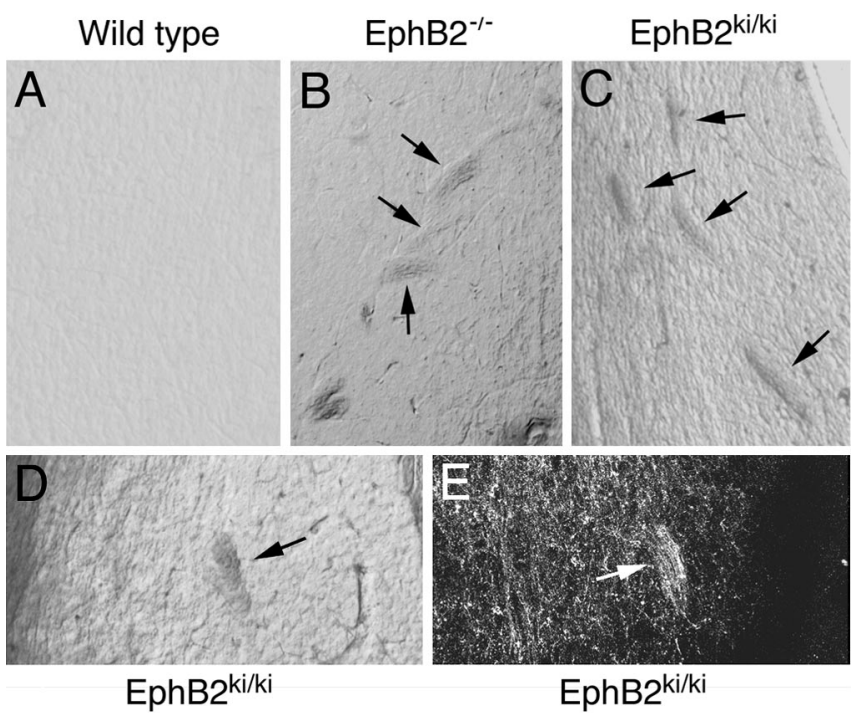

Figure 9. Proper hippocampal axon defasciculation is dependent on the cytoplasmic domain of EphB2. Fluoro-ruby was injected into the lateral hippocampus of adult mice that were allowed to survive for 1 week. The traced brains were then sectioned with a vibratome, and the sections were examined for the presence of axon bundles and the morphology of axon terminals in the lateral septum. $A$, Bright-field photomicrograph of a vibratome section from an adult wild-type mouse. $B$, Bright-field photomicrograph of a vibratome section from an adult EphB2 ${ }^{-1-}$ mouse. C, D, Bright-field photomicrographs of vibratome sections from two different adult EphB2 ${ }^{\text {ki/ki }}$ homozygous mice. $E$, The axon bundle shown in Dlabeled with Fluoro-ruby anterograde tracing.

hippocampus (Fig. 5). Consequently, in EphB2 ${ }^{-1-}$ EphB3 $3^{-1-}$ mice, no EphB function is present in the lateral hippocampus; however, EphB1 expressed in the medial hippocampus may allow axons from these neurons to defasciculate normally in response to ephrin-B3 expressed in the septum. Analysis of EphB1-B3 triple-mutant mice will likely clarify this issue.

\section{Multiple functions of ephrin-B3}

Several previous studies indicated that both ephrin-B1 and ephrin-B2 possess axon-repulsive activity and induce growth cone collapse (Meima et al., 1997; Wang and Anderson, 1997; Nakagawa et al., 2000); however, the effects of ephrin-B3 on axon growth and guidance are less well characterized. Ephrin-B3 is expressed in the midline cells of the spinal cord (Gale et al., 1996; Bergemann et al., 1998), and inactivation of this gene leads to abnormal crossing of corticospinal axons to the contralateral half of the spinal cord (Kullander et al., 2001b; Yokoyama et al., 2001). This suggests that, like ephrin-B1 and B2, ephrin-B3 can also have repulsive activities. Our in vitro analyses, however, revealed that ephrin-B3 had a different function in regulating hippocampal axons, i.e., promoting cell adhesion to ligand-expressing substrates. In addition, there are no significant effects of ephrin-B3 on hippocampal axon outgrowth under the culture conditions used here. It is possible that ephrin-B3 may have different effects on different types of axons, similar to netrin, an axon guidance molecule of a different family (Tessier-Lavigne and Goodman, 1996). Together, these observations indicate that ephrin-B3 may have multiple functions.

\section{Regulation of axon fasciculation and defasciculation and roles of Eph family receptors and ligands}

Whether axons fasciculate is determined by the relative strength of affinity among axons and between axons and the substrate on which axons travel. For example, increase of axon-axon affinity by upregulation of the cell adhesion molecule Fasciclin II (Fas II) leads to axon hyperfasciculation and misrouting (Lin et al., 1994). In contrast, decrease of axon-axon interaction by downregulating Fas II expression results in defasciculation (Lin et al., 1994). Conceivably, increase of axon-substrate interaction would also lead to defasciculation. During development, interaction between ephrin-B3 expressed in the septum and EphB2 and EphB3 expressed on hippocampal axons could regulate defasciculation through several potential mechanisms. First, the interaction may induce defasciculation either by downregulating cell adhesion to reduce axon-axon affinity or by upregulating repulsion to increase axon-axon repulsion. Second, ephrin-B3 may promote axon-target adhesion through interaction with the receptors EphB2 and EphB3 expressed on the axons. A similar mechanism has been proposed to regulate neural tube closure by interaction between ephrin-A5 and an EphA7 splice variant that lacks the kinase domain (Holmberg et al., 2000). In addition, it has been shown that EphB receptors and B-subclass ephrins regulate the dorsal-ventral topography of retinal axon terminals in the superior colliculus-optic tectum through adhesive-attractive mechanisms (Hindges et al., 2002; Mann et al., 2002). Consistent with these in vivo observations, EphB receptors and ligands promote cell adhesion in vitro (Bohme et al., 1996; Holash et al., 1997). The interaction between ephrin-B3 and EphB2/B3 may promote axon-target adhesion by promoting expression of cell adhesion molecules in the axons that adhere to the target cells. No matter which mechanism underlies EphB function, observations reported in this study indicate that these receptors play critical roles in proper hippocampal axon defasciculation.

\section{References}

Adams RH, Wilkinson GA, Weiss C, Diella F, Gale NW, Deutsch U, Risau W, Klein R (1999) Roles of ephrinB ligands and EphB receptors in cardiovascular development: demarcation of arterial/venous domains, vascular morphogenesis, and sprouting angiogenesis. Genes Dev 13:295-306.

Bergemann AD, Zhang L, Chiang MK, Brambilla R, Klein R, Flanagan JG (1998) Ephrin-B3, a ligand for the receptor EphB3, expressed at the midline of the developing neural tube. Oncogene 16:471-480.

Bohme B, VandenBos T, Cerretti DP, Park LS, Holtrich U, RubsamenWaigmann H, Strebhardt K (1996) Cell-cell adhesion mediated by binding of membrane-anchored ligand LERK-2 to the EPH-related receptor human embryonal kinase 2 promotes tyrosine kinase activity. J Biol Chem 271:24747-24752.

Cowan CA, Henkemeyer M (2002) Ephrins in reverse, park and drive. Trends Cell Biol 12:339-346.

Cowan CA, Yokoyama N, Bianchi LM, Henkemeyer M, Fritzsch B (2000) EphB2 guides axons at the midline and is necessary for normal vestibular function. Neuron 26:417-430.

Davy A, Robbins SM (2000) Ephrin-A5 modulates cell adhesion and morphology in an integrin-dependent manner. EMBO J 19:5396-5405.

Davy A, Gale NW, Murray EW, Klinghoffer RA, Soriano P, Feuerstein C, Robbins SM (1999) Compartmentalized signaling by GPI-anchored ephrin-A5 requires the Fyn tyrosine kinase to regulate cellular adhesion. Genes Dev 13:3125-3135.

Drescher U (2000) Eph receptor tyrosine kinases and their ligands in development. Ernst Schering Res Found Workshop 29:151-164.

Fambrough D, Goodman CS (1996) The Drosophila beaten path gene encodes a novel secreted protein that regulates defasciculation at motor axon choice points. Cell 87:1049-1058.

Flanagan JG, Vanderhaeghen P (1998) The ephrins and Eph receptors in neural development. Annu Rev Neurosci 21:309-345.

Franklin KBJ, Paxinos G (1997) The mouse brain in stereotaxic coordinates. San Diego: Academic.

Gale NW, Flenniken A, Compton DC, Jenkins N, Copeland NG, Gilbert DJ, Davis S, Wilkinson DG, Yancopoulos GD (1996) Elk-L3, a novel transmembrane ligand for the Eph family of receptor tyrosine kinases, expressed in embryonic floor plate, roof plate and hindbrain segments. Oncogene 13:1343-1352. 
Gao PP, Zhang JH, Yokoyama M, Racey B, Dreyfus CF, Black IB, Zhou R (1996) Regulation of topographic projection in the brain: Elf- 1 in the hippocamposeptal system. Proc Natl Acad Sci USA 93:11161-11166.

Grunwald IC, Korte M, Wolfer D, Wilkinson GA, Unsicker K, Lipp HP, Bonhoeffer T, Klein R (2001) Kinase-independent requirement of EphB2 receptors in hippocampal synaptic plasticity. Neuron 32:1027-1040.

Henderson JT, Georgiou J, Jia Z, Robertson J, Elowe S, Roder JC, Pawson T (2001) The receptor tyrosine kinase EphB2 regulates NMDA-dependent synaptic function. Neuron 32:1041-1056.

Henkemeyer M, Orioli D, Henderson JT, Saxton TM, Roder J, Pawson T, Klein R (1996) Nuk controls pathfinding of commissural axons in the mammalian central nervous system. Cell 86:35-46.

Hindges R, McLaughlin T, Genoud N, Henkemeyer M, O'Leary D (2002) EphB forward signaling controls directional branch extension and arborization required for dorsal-ventral retinotopic mapping. Neuron 35: 475-487.

Holash JA, Soans C, Chong LD, Shao H, Dixit VM, Pasquale EB (1997) Reciprocal expression of the Eph receptor Cek5 and its ligand(s) in the early retina. Dev Biol 182:256-269.

Holder N, Durbin L, Cooke J (2000) Eph receptors and ephrins are key regulators of morphogenesis. Ernst Schering Res Found Workshop 29:123-147.

Holmberg J, Clarke DL, Frisen J (2000) Regulation of repulsion versus adhesion by different splice forms of an Eph receptor. Nature 408:203-206.

Knoll B, Drescher U (2002) Ephrin-As as receptors in topographic projections. Trends Neurosci 25:145-149.

Knoll B, Zarbalis K, Wurst W, Drescher U (2001) A role for the EphA family in the topographic targeting of vomeronasal axons. Development 128:895-906.

Krull CE, Lansford R, Gale NW, Collazo A, Marcelle C, Yancopoulos GD, Fraser SE, Bronner-Fraser M (1997) Interactions of Eph-related receptors and ligands confer rostrocaudal pattern to trunk neural crest migration. Curr Biol 7:571-580.

Kullander K, Klein R (2002) Mechanisms and functions of Eph and ephrin signaling. Nat Rev Mol Cell Biol 3:475-486.

Kullander K, Mather NK, Diella F, Dottori M, Boyd AW, Klein R (2001a) Kinase-dependent and kinase-independent functions of EphA4 receptors in major axon tract formation in vivo. Neuron 29:73-84.

Kullander K, Croll SD, Zimmer M, Pan L, McClain J, Hughes V, Zabski S, DeChiara TM, Klein R, Yancopoulos GD, Gale NW (2001b) Ephrin-B3 is the midline barrier that prevents corticospinal tract axons from recrossing, allowing for unilateral motor control. Genes Dev 15:877-888.

Lillien L (1995) Changes in retinal cell fate induced by overexpression of EGF receptor. Nature 377:158-162.

Lin DM, Fetter RD, Kopczynski C, Grenningloh G, Goodman CS (1994) Genetic analysis of fasciclin II in Drosophila: defasciculation, refasciculation, and altered fasciculation. Neuron 13:1055-1069.

Linke R, Pabst T, Frotscher M (1995) Development of the hippocamposeptal projection in the rat. J Comp Neurol 351:602-616.

Mann F, Ray S, Harris W, Holt C (2002) Topographic mapping in dorsoventral axis of the Xenopus retinotectal system depends on signaling through ephrin-B Ligands. Neuron 35:461.

Meima L, Moran P, Matthews W, Caras IW (1997) Lerk2 (ephrin-B1) is a collapsing factor for a subset of cortical growth cones and acts by a mechanism different from AL-1 (ephrin-A5). Mol Cell Neurosci 9:314-328.

Mellitzer G, Xu Q, Wilkinson DG (1999) Eph receptors and ephrins restrict cell intermingling and communication. Nature 400:77-81.
Nakagawa S, Brennan C, Johnson KG, Shewan D, Harris WA, Holt CE (2000) Ephrin-B regulates the ipsilateral routing of retinal axons at the optic chiasm. Neuron 25:599-610.

Orioli D, Henkemeyer M, Lemke G, Klein R, Pawson T (1996) Sek4 and Nuk receptors cooperate in guidance of commissural axons and in palate formation. EMBO J 15:6035-6049.

Palmer A, Zimmer M, Erdmann KS, Eulenburg V, Porthin A, Heumann R, Deutsch U, Klein R (2002) EphrinB phosphorylation and reverse signaling. Regulation by Src kinases and PTP-BL phosphatase. Mol Cell 9:725-737.

Pasquale EB (1997) The Eph family of receptors. Curr Opin Cell Biol 9:608-615.

Rutishauser U (1985) Influences of the neural cell adhesion molecule on axon growth and guidance. J Neurosci Res 13:123-131.

Swanson LW, Kohler C, Bjorklund A (1987) The limbic region. I: The septohippocampal system. In: Handbook of chemical neuroanatomy (Bjorklund A, Hökfelt T, Swanson LW, eds), pp 125-277. Amsterdam: Elsevier.

Tessier-Lavigne M, Goodman CS (1996) The molecular biology of axon guidance. Science 274:1123-1133.

Thanos S, Bonhoeffer F, Rutishauser U (1984) Fiber-fiber interaction and tectal cues influence the development of the chicken retinotectal projection. Proc Natl Acad Sci USA 81:1906-1910.

Torres R, Firestein BL, Dong H, Staudinger J, Olson EN, Huganir RL, Bredt DS, Gale NW, Yancopoulos GD (1998) PDZ proteins bind, cluster, and synaptically colocalize with Eph receptors and their ephrin ligands. Neuron 21:1453-1463.

Wang HU, Anderson DJ (1997) Eph family transmembrane ligands can mediate repulsive guidance of trunk neural crest migration and motor axon outgrowth. Neuron 18:383-396.

Wang HU, Chen ZF, Anderson DJ (1998) Molecular distinction and angiogenic interaction between embryonic arteries and veins revealed by ephrin-B2 and its receptor Eph-B4. Cell 93:741-753.

Wilkinson DG (2000) Eph receptors and ephrins: regulators of guidance and assembly. Int Rev Cytol 196:177-244.

Winslow JW, Moran P, Valverde J, Shih A, Yuan JQ, Wong SC, Tsai SP, Goddard A, Henzel WJ, Hefti F, Beck KD, Caras IW (1995) Cloning of AL-1, a ligand for an Eph-related tyrosine kinase receptor involved in axon bundle formation. Neuron 14:973-981.

Xu Q, Mellitzer G, Robinson V, Wilkinson DG (1999) In vivo cell sorting in complementary segmental domains mediated by Eph receptors and ephrins. Nature 399:267-271.

Yokoyama N, Romero MI, Cowan CA, Galvan P, Helmbacher F, Charnay P, Parada LF, Henkemeyer M (2001) Forward signaling mediated by Ephrin-B3 prevents contralateral corticospinal axons from recrossing the spinal cord midline. Neuron 29:85-97.

Yu HH, Huang AS, Kolodkin AL (2000) Semaphorin-la acts in concert with the cell adhesion molecules fasciclin II and connectin to regulate axon fasciculation in Drosophila. Genetics 156:723-731.

Yue Y, Chen ZY, Gale NW, Blair-Flynn J, Hu TJ, Yue X, Cooper M, Crockett DP, Yancopoulos GD, Tessarollo L, Zhou R (2002) Mistargeting hippocampal axons by expression of a truncated Eph receptor. Proc Natl Acad Sci USA 99:10777-10782.

Zhang JH, Pimenta AF, Levitt P, Zhou R (1997) Dynamic expression suggests multiple roles of the Eph family receptor brain-specific kinase (Bsk) during mouse neurogenesis. Brain Res Mol Brain Res 47:202-214.

Zhou R (1998) The Eph family receptors and ligands. Pharmacol Ther 77: $151-181$. 